\title{
DESIGN AND EMPIRICAL TESTING OF A FRAMEWORK FOR IMPLEMENTING PFABC COSTING SYSTEMS
}

\author{
Mohammad Namazi ${ }^{1}$ and Zahra Sadat Hosseini ${ }^{2}$ \\ ${ }^{1}$ Shiraz University, Iran \\ E-mail:mnamazi@rose.shirazu.ac.ir \\ ${ }^{2}$ Shiraz University, Iran \\ E-mail: hosseinizahra@iauyasooj.ac.ir
}

\begin{abstract}
Performance Focused Activity Based Costing (PFABC) system is the third generation of the $\mathrm{ABC}$ systems. The major purposes of this study were: 1 . to design a framework for identifying constructs that should be selected for successful implementation of the PFABC system? And empirically test it and 2: to explain why there is a gap between theory and practice of this system? In achieving these objectives, content analysis, contingent theory, and innovation theory were employed. The statistical population consisted of all Tehran Stock Exchange (TSE) companies. In 2018, 450 questionnaires were sent to (TSE) corporate executives and 262 usable responses were collected. The Structural Modeling Equations (SME), SPSS and SMARTPLS software were employed to test related hypotheses and analyze the results. The results of the study clearly showed that environmental constructs $(0.997)$ had the greatest impact, followed by cost constructs (0.996), technological constructs (0.993) and finally organizational constructs ( 0.981$)$, respectively. However, there was no significant relationship between the desire to save, system integration, time of system implementation, and implementation of the PFABC costing system. These constructs are also the major imputes responsible for the existence of a gap between theory and practice. The application of $\mathrm{ABC}$, TDABC, and PFABC among TSE firms, was $6.1 \%$, $0.04 \%$ and $0 \%$, accordingly. Hence, there is a huge gap between theory and practice.
\end{abstract}

Keywords: PFABC costing system, organizational construct, technological construct, environmental construct, cost construct, SE

\section{ARTICLE INFO}

Article History:

Received: 5 June 2020

Accepted: 14 July 2020

Published: 31 December 2020 


\section{INTRODUCTION}

Traditionally, costing systems have played an essential role in the businesses, both in external and internal reporting, and have been used by various stakeholders including accountants, managers, auditors, and the government. These systems have also had major applications, particularly in the areas of inventory cost valuation, product pricing, taxes, and even product marketing (Zhang \& Isa, 2010; Jansen, 2018). In recent years, however, businesses are extremely changing; the prominent changes are: increasing competition, internationalization of markets, and emphasis on customer satisfaction, rapid growth of IT and technology changes, and expansion of strategic management accounting issues. These changes have forced professional managers as well as management accounting researchers to focus on the supplying qualitative strategic cost information, exploring relevant cost management systems, and studying the constructs affecting their use, more than ever before (Toompuua \& Põlajevaa, 2014).

Therefore, one of the most important challenges of today's strategic management accounting is identifying the constructs that influence the design and implementation of contemporary costing systems to respond to preceding issues (Askarany \& Yazdifar, 2007; Rickards \& Ritsert, 2018). In this vein, it is important to note that traditional cost accounting systems are retrospective, while strategic cost management systems are forward-looking and are adopted with the aim of predicting future complexities and providing relevant information in order to help stakeholders to make operational as well as strategic economic decisions (Toosi \& Chamikarpour, 2019). Hence, careful and accurate design of the cost system and its elements are the major imputes in attaining the efficiency and effectiveness of the costing system in pursuing the cost accounting objectives. It also enhances the fitness of the cost model to deal with practical issues which are intended to solve. Hence, it will increase the chances of being used in practice. In fact, empirical research (Akinyomi, 2014; Askarany \& Yazdifar, 2007; Kaplan \& Anderson, 2007) has shown that a significant construct which has led to the failure of adopting contemporary costing systems or eliminating them in practice, is the lack of necessary constructs for their successful implementation.

Another challenge regarding the preceding issue that is raised by some management accounting writers (for example, Cooper \& Kaplan, 
1988; Jansen, 2018), is the existing gap between theory and practice in the application of modern cost accounting systems. This issue raises the queries of: why modern cost management accounting techniques introduced in academic spheres, are not absorbed or less applied in practice? And how can this gap be reduced? (Namazi, 1998-1999). This gap, has also weakened the link between academicians and accounting professionals, and therefore the advantages, shortcomings, and applications of the costing systems in practice is in a haze of ambiguity and cannot be tested.

The literature of strategic management accounting shows that in addition to traditional cost accounting systems, three generations of Activity-Based Costing systems have been introduced so far: 1. ActivityBased Costing (ABC) (Johnson \& Kaplan, 1987; Cooper \& Kaplan, 1988) 2. Time-Driven Activity-Based Costing (TDABC) (Kaplan \& Anderson, 2007; Zhang \& Isa, 2010) and 3. Performance Focused Activity-Based Costing (PFABC) (Namazi, 2009; Carroll \& Lord, 2016). The discussion of the dimensions of the first two generations has been carried out widely in the world and to some extent in Iran and is still underway, but different aspects of the PFABC system and the construct affecting its implementation have not been thoroughly studied. Therefore, the significance of the important construct and considerations relating to the efficient and effective implementation of this system, has been ignored.

The main purpose of this study was to present a comprehensive framework for the successful implementation of modern costing systems and in particular the PFABC system and empirically test it. The study attempts to determine what are the effective constructs for implementing this system and how these constructs can be presented in an operational framework? And among the contingent constructs (organizational, technological, environmental, cost and other constructs) which of these posit the most impact? Finally, this study sought to introduce an optimal costing system to provide managers and other stakeholders with relevant and timely information (Reyhanoghlu, 2004), and explain the reasons for the current gap which exist between the theory and practice. In approaching these objectives, by applying "Contingent theory" (Madwe, 2017; Zhang, Namazi, \& Isa, 2017) and "Innovation theory" (Gosselin, 1997; Abrahamson, 1991), prominent organizational, technological, environmental, cost, and other constructs were identified and embedded in a conceptual framework. 
By utilizing descriptive statistics of the firms listed in the Tehran Stock Market (TSE), we found that among the TSE firms, the prominent costing systems are still traditional systems and only $6.1 \%$ of them use ABC and $0.4 \%$ adopted TDABC. Thus, there is a gap between theory and practice. By forming relevant hypotheses, obtaining required data from and utilizing Structural Equation Modelling (SEM), we concluded that the environmental constructs with the coefficient of (0.997) had the greatest impact, followed by cost constructs ( 0.996$)$, technological constructs $(0.993)$ and organizational constructs (0.981) respectively. However, there was no significant relationship between the construct related to other constructs (desire to save, system integration and time of system implementation) and implementation of the PFABC costing system.

In the following, first, the theoretical foundations of the research are presented in detail. Subsequently, studies on PFABC are presented. Then the research model, construct and hypotheses are expressed and finally the findings will be presented and the results analysed.

\section{THEORETICAL FOUNDATIONS}

\section{Contingent Theory}

One of the main goals of this study was to provide a framework for examining theoretical foundations of effective constructs of the PFABC systems. The theoretical foundations of this framework were developed on the "Contingent Theory " and " the Innovation Theory ". Contingency theory is based on the premise that the usefulness of management accounting techniques and systems, depends on the conditions of important and relevant exogenous and exogenous variables of the organization that affect the operations of the organization and vary across organizations. In fact, the contingent theory is an approach to study organizational behaviour that describes how contingent constructs such as technology, culture, external organizational environment, organizational design, and financial and nonfinancial performance have an influence on it (Madwe, 2017; Petera \& Soljakova, 2019). The underlying assumption of this theory in management accounting is that there is no single costing system that applies equally to all organizations. Dianatideilami, Alambeigi, and Khatibi (2016) state that 
this theory was created when the idea of a comprehensive management accounting system for all firms in all circumstances arose. Zhang et al. (2017) have proposed the following contingency framework for the successful implementation of a cost management system:

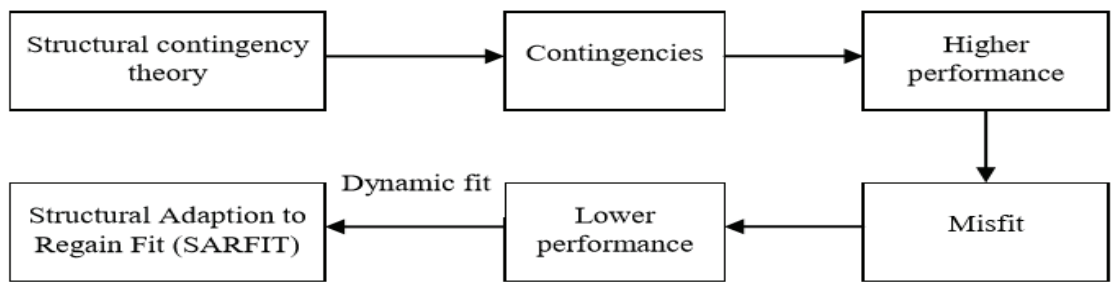

Figure 1: Framework of Contingent Theory (Zhang, et al. 2017; p: 179)

Figure 1 reveals that when the Contingency Theory is used by a firm to establish its cost management system based on such exogenous and endogenous factors as, technology, products, human resources, strategy and cultures, it is expected that the firm will attain a higher profit and a more favourable performance. However, when the firm is at the expansion stage, the scope of the firm's activities will rise, and the contingency structure of the firm's cost management system is no longer sufficient to provide a higher performance and growth for the firm. This situation would create the "misfit" of the current cost management structure of the firm, which ultimately leads to firm's lower performance. In this situation, the firm has to adopt a "dynamic fit" of the cost management system, which is adoptive and also susceptible to contextual contingent variables of the firm. By interacting the relevant attributes of the misfit and fit structure of the cost management system, the condition of restoring fitness of the cost management system with the new contingency variables will be achieved. This will result in implementing a new hybrid cost management system, and therefore will reduce the gap between theory and practice of cost management system. We believe adoption and diffusion of the PFABC and the existing gap between theory and practice in this regard can be explained within the framework of this theory since PFABC consists of various integrated contingent variables.

\section{Innovation Theory}

The Innovation Theory is also one of the applicable theories in management accounting and strategic costing systems. One definition views 
innovation as the first use of new knowledge, while in the other, innovation is recognized as the acceptance of a new strategy, products, systems, or services (Namazi \& Moghimi, 2018). Madwe (2017) believes that innovation can be a new "service" or "technology". Elagili (2015) regards innovation as a new "belief" that may be related to a program, system, policy, process, or service that results in responding to market needs. Rogers (1995) defines innovation as a "doctrine" or "practice" that is recognized as something new by individuals and institutions that accept it. The general criterion pertinent in all definitions of innovation is freshness (Askarany, Smith, \& Yazdifar, 2007).

The Innovation Theory evolved from different disciplines and thoughts. The Management Innovation Theory has been derived from the literature of Organizational Theory, and states that many firms' changes occur as a result of the direct appearance of the effects of innovation. The emergence of a contemporary management system or technology is a process that starts from dissatisfaction with existing systems and / or inspiration to change. Then it involves in following three consecutive stages: invention, internal and external validation of the new system or technology, and diffusion of the innovation to other firms (Birkinshaw \& Mol, 2006). This theory has progressed through three mainstream domains: 1) diffusion of a specific management innovation system or technology in practice, 2) developing appropriate theories with respect to how firms adopt a specific system or practice, and 3) studying management innovation fashion and fad (Harder, 2011). The Fashion Management innovation theory is based on the four typology of Abrahamson (1991): 1) efficient choice perspective, 2) forced selection perspective, 3) fashion perspective, and 4) fad perspective. According to the efficient perspective, firms based on the rational behaviour of the economic efficiency paradigm, arbitrarily and without any outside pressures choose proposed contemporary systems and technologies in order to attain their goals. The objective is to eliminate or reduce the gap between the firms' goals and actual practice. In the forced selection perspective, firms are compelled by the government or other legal agencies, to adopt systems, changes or prescribed technologies; thus, there is no choice in selecting systems, changes, or technologies on the part of the firms, and the imitation processes of the firms will not cause impelling towards adoption. The fashion perspective describes the process by which "fashion setters," such as consulting firms, media publications, and business 
professors, assimilate beliefs and promote certain management systems or techniques as the forefront of management innovations, and provoke firms to adopt the innovation. Thus, here rational behaviour of the firms adopting the innovating techniques is replaced mostly with psychological factors. The focus of this literature is to describe why some management innovations are diffused quickly and widely, but others do not. In the fad perspective, at first, an innovative system or technique is promoted as the leading new management tool, and then spreads widely and quickly among early adopters who are willing to obtain a competitive advantage. However, after realization of the disadvantages of the innovating system or technique and lack of its usefulness for the management's functions, the application of the new management technique is abundant (Namazi, 2016b). Thus, the major difference between the fashion and fad perspectives relates to sustainability characteristics of the fashion perspective.

The Management Innovation Theory can be used to explain emergence, diffusion, and applications of the PFABC system. As Askarany and Smith (2003) and Gosselin (1997) point out, traditional management and cost accounting systems may not be able to completely respond to the needs of the ongoing internal and external environmental changes because they require up-to-date, accurate, and detailed information. Accordingly, the implementation of recent technological changes in production processes and the expectation of detailed and, in some cases up-to-date information, coupled with existing organization failures can lead to the demand for contemporary management accounting techniques and more accurate systems. Shortcomings of the ABC and TDABC (Namazi, 2009; Ostadi, Daloie, \& Sepehri, 2019) and dissatisfaction of some companies in adopting these fashion techniques are also other imputes for the emergence and application of the PFABC (Namazi, 2016a; 2016b).

\section{RESEARCH BACKGROUND}

Traditional ideas of costing were common until the 1980's, finally in that decade, the ABC system was developed by Cooper and Kaplan. The ABC system is one of the greatest advances in management accounting in the 20 th century (Ghadimpour \& Shahvalizade, 2014). This system accurately determines the costs of the production and eliminates non -value activities. 
Thus, it increases the profitability of the company. The focus of any ABC system, that separates it from traditional systems, is identifying activities and related resources consumed by those activities accurately, and tracing costs in two stages: 1 . from resources to activities, and 2. from activities to the cost objects. Despite the benefits of this system over the traditional system, there are disadvantages such as complexity of operation, difficulty in gathering information, cost of updating the system and other problems associated with maintaining it (Kaplan \& Anderson, 2007; Namazi, 2016a). These problems, together with the exaggerations of the $\mathrm{ABC}$ system, became the most important reasons for the emergence of a new generation of costing systems (Namazi, 2016b). So about 15 years later, in 2004, the second generation of this system, Time-driven Activity-Based Costing (TDABC), was introduced by Kaplan and Anderson.

The TDABC system generally focuses only on temporal motion, and the method of implementation differs greatly from that of ABC (Sarokolaei, Saviz, Moradloo, \& Dahaj, 2013). It adopts "time", as the only cost driver, and assigns cost based on the rate of the total costs of the department divided by its prominent practical capacity, and then applies this rate to the amount of actual activities to determine the total costs applied in the department. (Kaplan \& Anderson, 2007). TDABC was created to solve obstacles of the $\mathrm{ABC}$ system, show the ideal capacity, and make the implementation of the costing system practical and easier, but its adoption has been slower than ABC's (Namazi, 2016b). The major problems with the TDABC are: 1. the possibility of being biased or corrupted by the information collected by the system and thus reducing the validity of this information to the current $\mathrm{ABC} ; 2$. the moral hazard problem; 3 . the lack of integration of this system and the need for two systems in the organization, one for calculating cost and the other for performance evaluation (Namazi, 2009).

In order to address the problems and disadvantages of both the TDABC and $\mathrm{ABC}$ systems, its third generation, Performance Focused Activity Based Costing (PFABC), was introduced by Namazi in 2009. The theory of the PFABC rests on the causal chain of the relationships which exists among committed and flexible costs of resources to activities, to the committed and flexible costs of the activities to cost objects, and finally to the performance evaluation criteria of the department or organization under the study. This chain of the relationships is followed by determining the 
exact behaviour of the committed and flexible costs, choosing appropriate quantitative and non-quantitative cost drivers, work measurement, and applying actual and standard costing systems, and dovetailing the system to the organization's productivity systems. Thus, PFABC, maintains the advantages of the $\mathrm{ABC}$ and TDABC, but eliminates their major obstacles. Unlike the $\mathrm{ABC}$ and TDABC systems, it is an integrated system which hybridizes the $\mathrm{ABC}$ information to performance evaluation systems, thus extending $\mathrm{ABC}$ to $\mathrm{ABM}$ domain, and hence combines attempts to extend the value of this managerial costing system as a means to examine organizational performance (Carroll \& Lord, 2016). In fact, this characteristic separates it from $A B C$ and TDABC systems. In summary, PFABC posits thee major advantages: 1 . accurate performance evaluation of the operations of the firms, 2. solving some of the prevalent cost allocation obstacles of the TDABC systems and 3. providing more relevant information than the $\mathrm{ABC}$ and TDABC systems for management decision makings. Figure 2 shows the nine steps to implement this system.

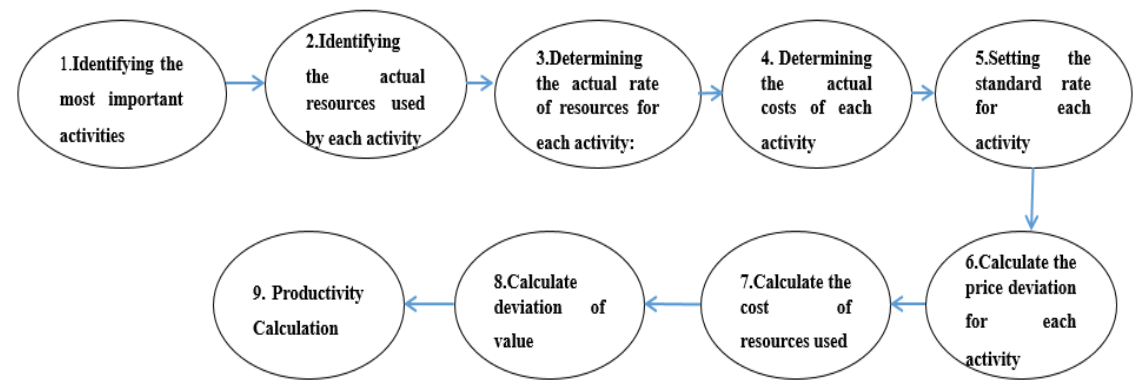

Figure 2: PFABC System Implementation Steps (Namazi, 2009; p: 36)

The major studies in the field of PFABC, after Namazi (2009), are as follows:

Some studies have attempted to describe the mechanism and implications of the PFABC system. For instance, Kowsari (2013), in her article "Changes in Costing Models from Traditional to PFABC", describes the changes in costing patterns and compares these changes and the benefits of these systems. She reviews the traditional costing system and describes its disadvantages and then introduces $\mathrm{ABC}$ and TDABC costing systems. Finally, she points to the emergence of PFABC and indicates that one of the advantages of this system is its flexibility in cost allocation and reporting 
various cost deviations which can be used for management analysis. Sarokolaei, Bahreini, and Bezenjani (2013) described characteristics and implementation steps of the PFABC system. They point out that unlike TDABC, which emphasizes time-based drivers, PFABC is more costeffective since it allocates resource costs of activities by choosing multiple cost drivers. PFABC also allocates actual costs separately to each activity using appropriate cost drivers and it is a useful technique for performance evaluation of the firms. The authors argue that this system, like other costing systems, faces ambiguity and uncertainty in estimating standards as system inputs. Hence, they extended the mechanism of the PFABC systems to the fuzzy systems. Carroll and Lord (2016) examined traditional, ABC, TDABC, PFABC, and other cost systems for controlling growing hospital costs in the United States. They point out that PFABC systems are useful because in the first implementation step, they explicitly identify relevant activities and map relating resource costs to those activities based on the associated cost behaviour. PFABC systems also provide more information regarding the operations and strategies of the hospitals; by providing information relating to the cost efficiencies, cost effectiveness, and cost variances of the hospitals, they show the ideal capacity and facilitate management decision makings. In summary, PFABC is a powerful planning and budgeting and performance evaluation tool for hospitals.

Some studies have attempted to actually apply the PFABC system in the manufacturing domain. For instance, Namazi and Shamsodini (2016) empirically investigated the impact of the cumulative average method and incremental approach of learning curves on the PFABC systems in a manufacturing company. The findings of the study showed that there is significant relationship between learning curves (cumulative average model and incremental model models) and PFABC systems. The study also indicates that learning curves posit an important effect in budget variance, efficiency variance, capacity variance, quantity variance, and effectiveness capacity, but has no effect in price variance. This finding shows that learning curves and the method of calculated learning, both provide important effect in costing and variances of the PFABC systems. Ali (2019), in 2015, actually applied the nine steps of the PFABC system to The General Company for Tire Industry in Najaf (Iraq) in an attempt to determine the productivity and efficiency of the company. This company is one of the subset of the companies which is under the supervision of the 
Ministry of Industry and Minerals of Iraq, and produces various sizes of tiers in different production lines. The result of the study showed that PFABC was successful and useful in showing: a) price variances, loading activities, and their additional costs, b) favourable and unfavourable operations and their causes, c) controlling production costs, d) inappropriateness of some activities for attainment of the efficiency of the company, d) presence of the unproductive and ideal capacity in the company, and e) existence of the surplus labour forces. In addition, there was a failure on the part of administrators and structure of the company to adopt contemporary cost accounting techniques for accurate determination of the product coasts. Toosi and Chamikarpour (2019) also investigated the problem of controlling costs and variances in the construction companies under the condition of competitive situations. After conducting content analysis and reviewing prevalent literature of the PFABC, they hybridized the PFABC system with target costing system (TCS) in an attempt to determine and reduce cost variances of the construction projects and control their respective budgets. In order to validate the proposed system, they interviewed with 26 financial managers of the construction companies, and used chi-square and Friedman tests to statistically determine the significance of this new model in comparison with the traditional system. The result of the study revealed that competitive ability of the new system for controlling construction costs is significantly more than the traditional system. The amount of precision and certainty increased, and mapping overhead costs to various projects raised 10 to 35 percent. It also showed different cost variances and revealed causes of the emergence of different variables; thus providing a vivid basis for controlling and evaluating the operations of the construction companies by managements in the competitive situations.

So far, most of the empirical studies relating to the application of the PFABC, however, have been in the domain of the service industries. For instance, Hassoun (2019) empirically examined the role of the PFABC costing system in achieving Institutional excellence at Babylon Bank in Iraq. Interviews were conducted with the head of different departments of the bank. The results of the study showed that PFABC is useful for attainment of the institutional excellence of the bank. Those parts of the bank that had used the PFABC system reported higher profitability with minimum variances than other sectors. It was also found that those segments performed significantly better than other segments of the bank. The author suggests that 
since PFABC reports favourable and unfavourable variances of the bank's operations, it can be used for various management decision making contexts at the banks. Moghri, Kordlouie, and Varmazyar (2019) first reviewed various systems for calculating current costs of different types of deposits at Sina Bank in Iran, and applied the PFABC system. Then, they empirically tested: a) possibility of designing the PFABC system for calculating various banking sources and deposits, and b) potential advantages of the PFABC over the traditional costing system of the bank. The findings of the study showed that traditional costing system did not provide correct information for determining costs of deposits; Instead PFABC assimilates relevant information regarding costs of different deposits, profitability, controlling overheads, and management decision making concerning combining bank deposits with capital structures and providing superior services to the customers. In addition, it is possible to design PFABC for any type of the banking deposits, and determine the efficiency and effectiveness of the various headquarters and branches of the bank.

An overview of the preceding studies unambitiously indicates that these studies have focused on the excellence mechanisms of the PFABC and assimilated some applications of the usefulness of it in the manufacturing as well as service industries. However, to date no comprehensive investigation has been exerted to identify and test the most influential constructs affecting the design and implementation process of the PFABC system. Lack of this information will cause that we will be deprived from maintaining a relevant and complete costing system to be effective in theory and practice. Furthermore, the issue of the long lasting of PFABC and its relevancy in solving practical problems will be in an aura of ambiguity. In addition, it will cause a gap between theory and practice. The major objective of this study was to eliminate the proceeding obstacles of the PFABC system.

\section{CONCEPTUAL RESEARCH MODEL AND HYPOTHESISES}

The literature on Innovation Theory (Birkinshow \& Mol, 2006; Greenacre, Groos, \& Speirs, 2012) to date has revealed that the reasons for adoption of a contemporary cost management technique may be: a) efficiency and competitive advantages of the new system in providing a superior 
performance for the firm, b) the result of dissatisfaction with status quo with prior systems, and c) inspiration from outside of the firm via the pattern of fashion. These factors will lead to invention, internal and external validation, and diffusion of a new system to other organizations. Nevertheless, little is known about the successful adoption of the contemporary systems (Harder, 2011). In this article, we provide another reason for adopting new systems and a successful implementation of them. Specifically, we contend that adoption and successful implementation of a new costing system (PFABC) also depends on the attributes and constructing factors which are devised in its development stage. A systematic investigation of various attributes of this cost system has not been explored in the management accounting literature yet. Hence, this analysis will provide an opportunity to investigate the casual relationships among innovation attributes of the new system to innovation adoption and successful implementation of it. The successful implementation of the system, will also reduce the prevalent gaps between theory and practice.

Generally, compiling a comprehensive model of constructs affective in designing and adopting PFABC systems, should encompass at least four following important issues:

(1) What are the organization's theoretical paradigms for designing and implementing costing system? (2) What important contingency construct should be considered in any organization with regard to its exogenous and endogenous variables to make the relevant costing system effective? (3) Why do cost systems work successfully in some organizations but fail in others? And (4) Why is there a gap between theory and practice in the use of costing systems? So far, some studies for identifying preceding influential issues affecting the traditional $\mathrm{ABC}$ and its subunits have been undertaken (Shields, 1995; Crumwiede, 1998; Brown, Booth, \& Giacobbe, 2004; Al-Omiri \& Drury, 2007; Askarany \& Smith, 2008; Akinyomi, 2013, 2014; Elajili, 2015; Madwe, 2017) and the significance of these issues has been reported; but no comprehensive model which incorporates the prominent features of the contingent constructs of the PFABC system has been developed. Figure 3 illustrates the general model of research based on the paradigms of contingent and innovation theory and prevalent research literature. 


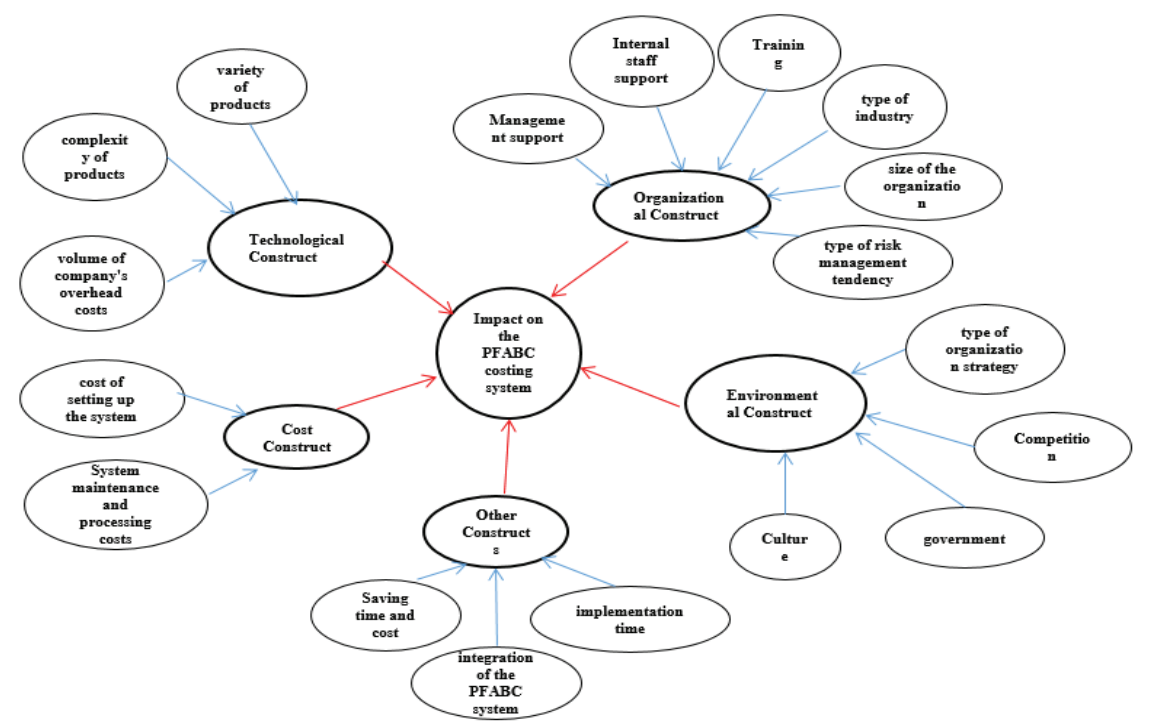

Figure 3: Structures Affecting PFABC Implementation

In approaching this model, took into account various features of the PFABC system along with comprehensive structures that ultimately lead to the performance of the organization. This was followed in two steps. In the first step, by adopting content analysis (Neuendorf, 2017), internal and external computer sites, and research backgrounds (internal and external) on modern costing systems, construct that are effective in implementing PFABC systems, were identified. The second step involved in dividing the literature into the following 5 general categories based on their characteristics: (1) Organizational construct (2) Technological construct (3) Environmental construct (4) Cost construct and (5) Other construct. The reason for using this classification is that Shields (1995) unambitiously states that merely focusing on technology construct and not considering other organizational constructs, is an important factor in the failure of organizations in adopting, diffusion, and implementation of the $\mathrm{ABC}$ system. Therefore, he proposes a framework based on the organizational and technological construct. Brown et al. (2004) have also addressed environmental construct in designing systems. Therefore, in the present study, the construct introduced by Shields (1995) and Brown et al. (2004) were used. Table 1 also reveals other resources extracted for our conceptual model. It also shows the causal relationship between each construct and the design of the PFABC system. 
In order to study each construct more closely, the relevant subsets were identified based on the above keywords. Table 1 shows the information on construct and indicators.

\section{Table 1: Research Constructs and Indicators}

\section{Variables (Constructs) and Indicators for Measuring Variables}

\section{Organizational Construct:}

A) Management Support: It is possible to determine the impact of this variable through the following structures: 1- Managers' approach 2- Financial support (incentive) of senior management 3- Spiritual Support (Brown et al., 2004; Zhang \& Isa, 2010; Akinyomi, 2013; Elagili, 2015; Madwe, 2017; Namazi \& Nazemi, 2015).

B) Internal support for employees: It is possible to determine the extent of the impact of this variable through the following structures: 1- Employee trust in the system 2-Intermediate managers support of the system 3- Operational managers support of the system (Shields, 1995; Brown et al., 2004; Elagili, 2015).

C) Training: Determining the impact of this variable is possible through the following structures: 1- Senior Management 2- Middle Managers 3- Operational Managers 4- Employees (Shields, 1995; Brown et al., 2004; Zhang \& Isa, 2010; Madwe , 2017; Namazi \& Nazemi, 2015).

D) Industry Type: It is possible to determine the impact of this variable through the following structures:

1- Chemical industry 2- Food industry 3- Banking and credit industry 4- Petroleum product industry 5- Insurance industry 6- Engineering industry 7- Automotive industry (Brown et al., 2004; Abusalama, 2008; Ahmadzadeh, Etemadi, \& Pifeh, 2011; Askarany, Yazdifar, \& Askary, 2010; Askarany, Brierley, \& Yazdifar, 2012).

E) Size of the organization: It is possible to determine the impact of this variable through the following structures (number):

1- Under 20 2- Between 20 - 50 3- Between 50 - 100 4- Between 100 - 500 5- Over 500 (Brown et al., 2004; Al-Omiri \& Drury, 2007; Abusalama, 2008; Askarany et al., 2012; Akinyomi, 2013; Elagili , 2015; Arora \& Raju, 2017).

F) Risk Management Tendency: The extent of the influence of this variable can be determined through the following construct: 1- Risk averse 2- Risky 3- Indifferent to risk (Cooper \& Kaplan, 1988).

\section{Technological Construct:}

A) Variety of products: It is possible to determine the impact of this variable through the following structures(number):

1-10 Products 2- Between 10 and 30 Products 3- Between 30-60 Products 4- Between 60-100 Products 5- Over 100 Products (Krumwiede, 1998; Brown et al., 2004; Al-Omiri \& Drury, 2007; Ahmadzadeh et al., 2011; Akinyomi, 2013, 2014; Elagili, 2015; Madwe, 2017).

B) Product Complexity: It is possible to determine the effect of this variable through the following structures:

1- Production in more than one stage 2- Using different materials 3- Using sophisticated and different devices 4- Requiring high technical knowledge and management (Brown et al., 2004).

C) Overhead volume: It is possible to determine the impact of this variable through the following structures million tomans:

1- under 50, 2- between 50 to 100, 3- between 100 to 500, 4- above 500

(Brown et al., 2004; Elagili, 2015; Namazi \& Nazemi, 2015). 


\section{Environmental Construct:}

A) The type of organization strategy: It is possible to determine the impact of this variable through the following structures: 1- Foresight strategy 2- Defensive strategy 3- Analytical strategy 4- Reactional strategy (Gosselin, 1997; Askarany et al., 2010).

B) Competition: It is possible to determine the impact of this variable through the following structures:

1- at the Local Level 2- at the Regional Level 3- at the National Level 4- at the World Level (Brown et al., 2004; Al-Omiri \& Drury, 2007; Abusalama, 2008; Askarany et al., 2010; Akinyomi, 2013; Elagili, 2015).

C) Role of Government: The extent of the impact of this variable can be determined through the following structures: 1- Government 2- Organization of Economic Affairs and Finance 3- Consumer Protection Organization 4- Ministry of Industries and Mines 5- Majlis 6- Civil Accounting Court 7- Management and Planning Organization 8- Audit Organization 9Society of Certified Accountants and Auditors 10- Educational Institutions (Brown et al., 2004; Namazi \& Nazemi, 2015).

D) Culture: It is possible to determine the impact of this variable through the following structures:

1- Organizational Management Culture 2- Organizational Culture 3- Workplace Culture 4- Community Culture (Abusalama, 2008; Nagirikandalage \& Binsardi, 2017).

\section{Cost Construct:}

A) System deployment cost: It is possible to determine the impact of this variable through the following structures million Tomans: 1- Under 20, 2- Between 20 to 60, 3- Over 60 (Cooper \& Kaplan, 1988).

B) Maintenance and Processing Costs: The following variables can be determined by the impact of these variables: 1- Software costs 2- Hardware costs 3- IT costs 4- Value chain costs 5- Other system costs (Ahmadzadeh et al., 2011; Elagili, 2015; Madwe, 2017).

\section{Other Constructs:}

A) It is possible to determine the impact of this variable through the following structures: 1System saving 2- System integration 3- System run time (Rogers, 1995; Gosselin, 1997; Askarany \& Smith, 2003; 2008; Askarany et al., 2007; Al-Omiri \& Drury, 2007; Madwe, 2017; Akinyomi, 2014; Namazi, 2016b; Nagirikandalage \& Binsardi, 2017).

\section{RESEARCH METHODOLOGY}

The present study was a quantitative and descriptive survey study. It was also an applied research because it sought to explore a new and cost-effective accounting system in the accounting world and examine the construct that influence its implementation in the real world. The statistical population of the study were all the companies of Tehran Stock Exchange (TSE) in 2018. Since the survey of constructs were carried out by experts, the managers of different sections of the listed companies were considered as the statistical population. Since there is always a possibility of not responding to all questionnaires which were sent to companies, all companies listed on the 
stock exchange were selected as sample to increase the response and validity of the research and no sampling was made.

\section{Research Hypotheses}

According to the illustrated construct in the conceptual model, the relevant hypotheses were expressed. Table 2 shows the hypotheses.

Table 2: Research Hypotheses

\section{Organizational Construct: \\ Main and Secondary Hypotheses}

1) Organizational constructs influence the implementation of the PFABC system. 1-1) Management support has an impact on the implementation of the PFABC system.

2-1) Internal staff support has an impact on the implementation of the PFABC system.

3-1) Training has an impact on the implementation of the PFABC system.

4-1) The type of industry has an impact on the implementation of the PFABC system.

5-1) The size of the organization affects the implementation of the PFABC system.

6-1) The type of risk management tendency influences the implementation of the PFABC system.

\section{Technological Construct:}

2) Technology-based constructs influence the implementation of the PFABC system.

1-2) The variety of products affects the implementation of the PFABC costing system.

2-2) The complexity of products affects the implementation of the PFABC costing system.

3-2) The volume of company's overhead costs impacts the implementation of the PFABC system.

\section{Environmental Construct}

3) Environmental constructs influence the implementation of the PFABC system.

1-3) The type of organization strategy affects the implementation of the PFABC system.

2-3) Competition affects the implementation of the PFABC system.

3-3) The government has influence over the implementation of the PFABC system.

4-3) Culture influences the implementation of the PFABC system. 


\section{Cost Construct:}

4) System costs have an impact on the implementation of the PFABC costing system.

1-4) The cost of setting up the system affects the implementation of the PFABC costing system.

2-4) System maintenance and processing costs affect the implementation of the PFABC costing system.

\section{Other Constructs:}

5) Other constructs influence the implementation of the PFABC costing system.

1-5) Saving (time and cost) affects the implementation of the PFABC costing system.

2-5) The integration of the PFABC system with other departments has an impact on the implementation of the PFABC costing system

3-5) The implementation time of the PFABC system has an impact on its implementation.

\section{Population of The Study}

The statistical population of the study encompassed all active companies listed in the Tehran Stock Exchange (TSE) in 2018. In total, 450 companies were identified. Since the possibility of not receiving enough responds was high, no sampling was attempted, and all TSE companies were considered as a population in order to increase the response rate and validity of the research. Consequently, the cost or management accountants or managers who were involved in costing systems of different TSE companies were identified and considered for this study. The reason for selecting TSE as a population study was familiarity of the researchers with this stock market, ease of obtaining information, and providing evidence from a growing stock market in a developing country.

\section{Data Collection Method}

A questionnaire was the main tool for data collection in this research. It was designed according to the features of the PFABC system, which consisted of five groups including construct that affect the implementation of the PFABC system. In total the questionnaire comprised 72 questions for various construct ( 25 questions for organizational construct, 13 questions for technological construct, 22 questions for environmental construct, 8 questions for cost construct, and 4 questions for other construct). Questions 
are divided into two categories: 1. Multiple Choice Questions: All general information questions are in this section (7 questions). 2. Likert spectrum questions: This spectrum is five classes and each spectrum is given a number indicating the importance of each answer. Questions in this spectrum, examined the impact of construct on the PFABC costing system: (very low impact (1), low impact (2), medium impact (3), high impact (4), very high impact (5)). In this study, "face validity approach" was undertaken to attain reliability (Smith, 2019). Hence to assess the validity of the questionnaire, the opinions of accounting professors, doctoral students of accounting and a number of people working in different industries were used. Also, through library search, articles, books, and collecting preliminary results, all ambiguities were identified and resolved. The reliability of the questionnaire was calculated by Cronbach's alpha. Cronbach's alpha for this study was approximately $82 \%$. Totally, 450 questionnaires were sent to active and listed companies in TSE and finally 262 replies were usable. The questionnaire was designed and submitted electronically. SPSS software version 23 and SMARTPLS software version 3 were used for data analysis. Structural equations were also used for statistical analysis of the hypotheses.

\section{RESEARCH RESULTS}

\section{Descriptive Results}

Table 3 presents the sociological information of the study. The gender of the respondents shows that $64.1 \%$ of them were male. The level of education of all the respondents is higher than diploma and most of the respondents were masters degree holders $(39.7 \%)$. The age data showed that the majority of these individuals $(41.2 \%)$ were 40 to 50 years old. The majority of respondents $(24 \%)$ worked in the education sector of the organization (based on the follow-up of these companies, it was found that most companies hold their organization's training department responsible for research cases. The above statistics also support this point). The $20.2 \%$ of respondents were from the cement industries and investment firms. The auto industry, with $0.04 \%$, was in the last place. Work experience statistics show that $30.2 \%$ of the respondents had $15-20$ years of work experience. According to this information, no TSE company used the PFABC system. $61.5 \%$ of companies use traditional costing systems. $6.1 \%$ of them used the 
$\mathrm{ABC}$ system, and $0.4 \%$ of companies use TDABC system. Also, $32.1 \%$ of companies used other systems.

Table 3: Descriptive Results of the Questionnaire

\begin{tabular}{|c|c|c|c|c|c|c|c|c|c|c|c|c|c|}
\hline gender & $\%$ & education & $\%$ & Age & $\%$ & $\begin{array}{l}\text { Organizational } \\
\text { position }\end{array}$ & $\%$ & industry & $\%$ & $\begin{array}{c}\text { Work } \\
\text { experience }\end{array}$ & $\%$ & system & $\%$ \\
\hline male & 64.1 & $\begin{array}{l}\text { High } \\
\text { school }\end{array}$ & o & $20-30$ & 11.5 & $\begin{array}{l}\text { training } \\
\text { section }\end{array}$ & 22.5 & investment & 17.6 & $\begin{array}{c}\text { Under } 5 \\
\text { years }\end{array}$ & $8 \%$ & $\begin{array}{c}\text { Traditional } \\
\text { systems }\end{array}$ & 61.5 \\
\hline female & 35.9 & Diploma & $\mathbf{0}$ & $30-40$ & 28.2 & $\begin{array}{l}\text { financial } \\
\text { manager }\end{array}$ & 13.7 & Chemical & 3.1 & $5-10$ & 18.7 & $A B C$ & 6.1 \\
\hline & & $\begin{array}{c}\text { Associate } \\
\text { Degree }\end{array}$ & 8.8 & $40-50$ & 41.2 & $\begin{array}{l}\text { Managing } \\
\text { Director }\end{array}$ & 1.5 & $\begin{array}{l}\text { Banks and } \\
\text { Credit } \\
\text { Institutions }\end{array}$ & 7.3 & 10-15 & 28.2 & TDABC & .4 \\
\hline & & Master & 25.2 & $50-60$ & 16.8 & Accountant & $21 \div 8$ & $\begin{array}{c}\text { automobile } \\
\text { manufacturing }\end{array}$ & .04 & $15-20$ & 30.2 & PFABC & $\mathbf{0}$ \\
\hline & & MA & 39.7 & $\begin{array}{c}\text { Above } \\
60\end{array}$ & 2.3 & $\begin{array}{c}\text { sales } \\
\text { department }\end{array}$ & 11.5 & Medicinal & $4: 2$ & Above 20 & 14.9 & other & 32.1 \\
\hline & & Doctorate & 26.3 & & & $\begin{array}{l}\text { producing } \\
\text { section }\end{array}$ & $3: 1$ & dietary & $9<2$ & & & & \\
\hline & & & & & & $\begin{array}{l}\text { Employee of } \\
\text { other } \\
\text { departments }\end{array}$ & $6: 9$ & Ceramic Tile & $4: 6$ & & & & \\
\hline & & & & & & other & $19: 1$ & Engineering & $4: 6$ & & & & \\
\hline & & & & & & & & Cement & $20 \div 2$ & & & & \\
\hline & & & & & & & & $\begin{array}{c}\text { Pension } \\
\text { insurance }\end{array}$ & $6 \times 1$ & & & & \\
\hline & & & & & & & & $\begin{array}{c}\text { Petroleum } \\
\text { product }\end{array}$ & $1 \star 1$ & & & & \\
\hline & & & & & & & & $\begin{array}{c}\text { Other } \\
\text { Industries }\end{array}$ & 21.8 & & & & \\
\hline
\end{tabular}

\section{Inferential Results}

In order to attain the objective of the study, test the conceptual model, and following our connotation that a major reason for adopting an innovative cost technique (PFABC) relates to identifying potent constructs of the PFABC, inferential statistics were utilized. Table 4 shows the information about the correlation between the study variables. The relationship between all constructs (except organizational and cost construct) was significant. The intensity of all relationships is not strong. The same is true for all relationships. 
Table 4: Pearson Correlation Coefficient of the Constructs

\begin{tabular}{|c|c|c|c|c|c|c|}
\hline & & $\begin{array}{l}\text { Organizational } \\
\text { Construct }\end{array}$ & $\begin{array}{c}\text { Technology } \\
\text { Construct }\end{array}$ & $\begin{array}{c}\text { Environmental } \\
\text { Construct }\end{array}$ & $\begin{array}{c}\text { Cost } \\
\text { Construct }\end{array}$ & $\begin{array}{c}\text { Other } \\
\text { Construct }\end{array}$ \\
\hline \multirow{3}{*}{$\begin{array}{l}\text { Organizational } \\
\text { Construct }\end{array}$} & Pearson Correlation & 1 & $.282^{* * *}$ & $.373 * *$ & .067 & $.215 * *$ \\
\hline & Sig.(2-tailed) & . & .000 & .000 & .277 & .000 \\
\hline & $\mathrm{N}$ & 262 & 262 & 262 & 262 & 262 \\
\hline \multirow{3}{*}{$\begin{array}{l}\text { Technology } \\
\text { Construct }\end{array}$} & Pearson Correlation & $.282 * *$ & 1 & $.216 * *$ & $.245 * *$ & $.312 * *$ \\
\hline & Sig.(2-tailed) & .000 & . & .000 & .000 & .000 \\
\hline & $\mathrm{N}$ & 262 & 262 & 262 & 262 & 262 \\
\hline \multirow{3}{*}{$\begin{array}{l}\text { Environmental } \\
\text { Construct }\end{array}$} & Pearson Correlation & $.373 * *$ & $216^{* *}$ & 1 & $.178 * *$ & $.243 * *$ \\
\hline & Sig.(2-tailed) & .000 & .000 & . & .004 & .000 \\
\hline & $\mathrm{N}$ & 262 & 262 & 262 & 262 & 262 \\
\hline \multirow{3}{*}{$\begin{array}{c}\text { Cost } \\
\text { Construct }\end{array}$} & Pearson Correlation & .067 & $.245^{* *}$ & $.178 * *$ & 1 & $.320 * *$ \\
\hline & Sig.(2-tailed) & .277 & .000 & .004 & . & .000 \\
\hline & $\mathrm{N}$ & 262 & 262 & 262 & 262 & 262 \\
\hline \multirow{3}{*}{$\begin{array}{c}\text { Other } \\
\text { Construct }\end{array}$} & Pearson Correlation & $.215 * *$ & $.312 * *$ & $.243 * *$ & $.320 * *$ & 1 \\
\hline & Sig.(2-tailed) & .000 & .000 & .000 & .000 & . \\
\hline & $\mathrm{N}$ & 262 & 262 & 262 & 262 & 262 \\
\hline
\end{tabular}

** Correlation is significant at the 0.01 level(2-tailed)

Considering the importance of the preceding relationships, the structural equations and SMARTPLS software were used to analyse the hypotheses. According to the principles of this method, after formulating the constructs, two types of measurement models are proposed: Reflective and Formative measurement models. In this study, as the constructs are a combination of questions or measures, and among the questions any pattern can exist (positive, negative, or non-relationship), the pattern is formative (Azar \& Gholamzadeh, 2016). Table 5 shows information on the formative pattern. 
Asia-Pacific Management Accounting Journal, Volume 15 Issue 3

Table 5: Results of Formative Measurement Models

\begin{tabular}{|c|c|c|c|c|c|c|c|c|}
\hline Construct & $\begin{array}{l}\text { Iofelestive } \\
\text { construct }\end{array}$ & $\begin{array}{l}\text { Infelective } \\
\text { indicators }\end{array}$ & $\begin{array}{l}\text { Exterior } \\
\text { weight } \\
\text { (load) }\end{array}$ & $\begin{array}{l}\text { t- } \\
\text { statistic }\end{array}$ & VIF & AVE & $\begin{array}{l}\text { Cronbach's } \\
\alpha\end{array}$ & CR \\
\hline \multirow{15}{*}{ Organizational } & \multirow[t]{3}{*}{$\begin{array}{l}\text { Management } \\
\text { support }\end{array}$} & $\begin{array}{l}\text { Manager's } \\
\text { approach(a1) }\end{array}$ & $.111(.492)$ & 8.03 & 1.61 & \multirow{15}{*}{.817} & \multirow{15}{*}{.779} & \multirow{15}{*}{.828} \\
\hline & & $\begin{array}{l}\text { Manager } \\
\text { financial } \\
\text { support(a2) }\end{array}$ & $1.022(1)$ & 12.902 & 1.841 & & & \\
\hline & & $\begin{array}{l}\text { Manager's } \\
\text { spiritual } \\
\text { support(a3) }\end{array}$ & $.032(.658)$ & .272 & 1.903 & & & \\
\hline & \multirow{2}{*}{$\begin{array}{c}\text { Internal staff } \\
\text { support }\end{array}$} & Staff trust(b1) & $1.099(.994)$ & 13.61 & 1.878 & & & \\
\hline & & $\begin{array}{l}\text { Operational } \\
\text { Manager } \\
\text { Support(b3) }\end{array}$ & $.08(.378)$ & 3.838 & 2.321 & & & \\
\hline & \multirow[t]{2}{*}{ Training } & Chief(e1) & $.494(.906)$ & 1.895 & 1.95 & & & \\
\hline & & $\begin{array}{l}\text { Mid-1eve1 } \\
\text { manager(c2) }\end{array}$ & $.591(.935)$ & 2.276 & 1.95 & & & \\
\hline & \multirow[t]{2}{*}{ type of industry } & Chemical(d1) & $.739(.101)$ & 2.242 & 1.712 & & & \\
\hline & & Bank(d3) & $1.302(.825)$ & 10.241 & 1.712 & & & \\
\hline & \multirow{4}{*}{$\begin{array}{l}\text { size of the } \\
\text { organization } \\
\text { (Number of } \\
\text { Employees) }\end{array}$} & $\begin{array}{l}\text { Between 20- } \\
50(e 2)\end{array}$ & $.349(.877)$ & 6.649 & 2.404 & & & \\
\hline & & $\begin{array}{l}\text { Between 50- } \\
100(e 3)\end{array}$ & $.257(.896)$ & 4.139 & 3.088 & & & \\
\hline & & $\begin{array}{l}\text { Between 100- } \\
\text { s00(e4) }\end{array}$ & $.393(.916)$ & 6.544 & 3.644 & & & \\
\hline & & Over $500(e 5)$ & $.125(.833)$ & 2.04 & 3.046 & & & \\
\hline & \multirow{2}{*}{$\begin{array}{l}\text { type of risk } \\
\text { management } \\
\text { tendency }\end{array}$} & Risk averse(f1) & $.154(.748)$ & .542 & 1.801 & & & \\
\hline & & $\begin{array}{l}\text { Indifferent to } \\
\text { risk(f3) }\end{array}$ & $.891(.993)$ & 4.257 & 1.801 & & & \\
\hline
\end{tabular}

\begin{tabular}{|c|c|c|c|c|c|c|c|c|}
\hline Construct & $\begin{array}{l}\text { Infelective } \\
\text { construct }\end{array}$ & $\begin{array}{l}\text { Infelective } \\
\text { indicators }\end{array}$ & $\begin{array}{l}\text { Exterior } \\
\text { weight } \\
\text { (load) }\end{array}$ & $\begin{array}{l}\text { t- } \\
\text { statistic }\end{array}$ & VIF & AVE & $\begin{array}{l}\text { Cronbach's } \\
\alpha\end{array}$ & CR \\
\hline \multirow{11}{*}{ Technological } & \multirow{3}{*}{$\begin{array}{l}\text { variety of } \\
\text { products } \\
\text { (number) }\end{array}$} & $\begin{array}{l}\text { Between } 10- \\
30(\mathrm{~g} 2)\end{array}$ & $.418(.768)$ & 3.199 & 1.443 & \multirow{11}{*}{.852} & \multirow{11}{*}{.826} & \multirow{11}{*}{.862} \\
\hline & & $\begin{array}{l}\text { Between } 60- \\
100(\mathrm{~g} 4)\end{array}$ & $.33(.889)$ & 2.205 & 2.59 & & & \\
\hline & & Over $100(\mathrm{~g} 5)$ & $.455(.847)$ & 2.912 & 2.083 & & & \\
\hline & \multirow{4}{*}{$\begin{array}{l}\text { complexity of } \\
\text { products }\end{array}$} & $\begin{array}{l}\text { More than } 1 \\
\text { step(h1) }\end{array}$ & $.221(.666)$ & 2.625 & 1.376 & & & \\
\hline & & $\begin{array}{l}\text { Different } \\
\text { materials(h2) }\end{array}$ & $.527(.832)$ & 6.929 & 1.328 & & & \\
\hline & & $\begin{array}{l}\text { Different } \\
\text { devices(h3) }\end{array}$ & $.259(.766)$ & 3.199 & 1.76 & & & \\
\hline & & $\begin{array}{l}\text { High technical } \\
\text { knowledge(h4) }\end{array}$ & $.297(.727)$ & 3.949 & 1.612 & & & \\
\hline & \multirow{4}{*}{$\begin{array}{l}\text { volume of } \\
\text { company's } \\
\text { overhead costs } \\
\text { (Million } \\
\text { Jomans) }\end{array}$} & Under SO(i1) & $.265(.831)$ & 2.957 & 3.052 & & & \\
\hline & & $\begin{array}{l}\text { Between 50- } \\
100 \text { (i2) }\end{array}$ & $.31(.771)$ & 3.524 & 4.18 & & & \\
\hline & & $\begin{array}{l}\text { Between100- } \\
500 \text { (i3) }\end{array}$ & $.322(.888)$ & 4.845 & 2.676 & & & \\
\hline & & Over 500(i4) & $.282(.759)$ & 4.298 & 1.71 & & & \\
\hline
\end{tabular}




\begin{tabular}{|c|c|c|c|c|c|c|c|c|}
\hline Construct & $\begin{array}{l}\text { Infelective } \\
\text { construct }\end{array}$ & $\begin{array}{l}\text { Infelective } \\
\text { indicators }\end{array}$ & $\begin{array}{l}\text { Exterior } \\
\text { weight } \\
\text { (load) }\end{array}$ & $\begin{array}{l}\text { t- } \\
\text { statistic }\end{array}$ & VIF & AVE & $\begin{array}{l}\text { Cronbach's } \\
\alpha\end{array}$ & CR \\
\hline \multirow{10}{*}{ Invicenmental } & \multirow{2}{*}{$\begin{array}{c}\text { type of } \\
\text { organization } \\
\text { strategy }\end{array}$} & Euturistics(j1) & $.566(.839)$ & 6.104 & 1.253 & \multirow{10}{*}{.811} & \multirow{10}{*}{.818} & \multirow{10}{*}{.859} \\
\hline & & Reactional(j4) & $.609(.863)$ & 6.789 & 1.253 & & & \\
\hline & \multirow[t]{2}{*}{ Competition } & regional(k2) & $.46(.898)$ & 5.597 & 1.996 & & & \\
\hline & & Country(k3) & $.62(.945)$ & 7.868 & 1.996 & & & \\
\hline & \multirow{4}{*}{ government } & Government(11) & $.347(.782)$ & 6.043 & 1.494 & & & \\
\hline & & $\begin{array}{l}\text { Industries and } \\
\text { Mines(13) }\end{array}$ & $.214(.692)$ & 3.729 & 1.584 & & & \\
\hline & & Auditors(18) & $.297(.76)$ & 5.219 & 1.677 & & & \\
\hline & & $\begin{array}{l}\text { Educational } \\
\text { institutions(110) }\end{array}$ & $.431(.821)$ & 7.378 & 1.486 & & & \\
\hline & \multirow[t]{2}{*}{ Culture } & Manager $(\mathrm{m} 1)$ & $.75(.951)$ & 7.730 & 1.423 & & & \\
\hline & & Society $(\mathrm{m} 4)$ & $.369(.778)$ & 3.145 & 1.423 & & & \\
\hline
\end{tabular}

\begin{tabular}{|c|c|c|c|c|c|c|c|c|}
\hline Construct & $\begin{array}{l}\text { Infelective } \\
\text { construct }\end{array}$ & $\begin{array}{l}\text { Infelective } \\
\text { indicators }\end{array}$ & $\begin{array}{l}\text { Exterior } \\
\text { weight } \\
\text { (load) }\end{array}$ & $\begin{array}{l}\text { t- } \\
\text { statistic }\end{array}$ & VIF & AVE & $\begin{array}{l}\text { Cronbach's } \\
\alpha\end{array}$ & CR \\
\hline \multirow{7}{*}{ Cost } & \multirow{2}{*}{$\begin{array}{l}\text { cost of setting } \\
\text { up the system } \\
\text { (Million } \\
\text { Jomans) }\end{array}$} & Under 20(n1) & $.814(.974)$ & 7.584 & 1.503 & \multirow{7}{*}{.805} & \multirow{7}{*}{.838} & \multirow{7}{*}{.879} \\
\hline & & Over 60(n3) & $.276(.748)$ & 1.965 & 1.503 & & & \\
\hline & \multirow{5}{*}{$\begin{array}{c}\text { System } \\
\text { maintenance } \\
\text { and } \\
\text { processing } \\
\text { costs }\end{array}$} & $\begin{array}{l}\text { Software } \\
\text { update(o1) }\end{array}$ & $.31(.828)$ & 10.518 & 2.129 & & & \\
\hline & & $\begin{array}{l}\text { Hardware } \\
\text { update(०2) }\end{array}$ & $.296(.857)$ & 10.453 & 2.384 & & & \\
\hline & & Cost of IT(03) & $.203(.816)$ & 7.379 & 2.3 & & & \\
\hline & & $\begin{array}{l}\text { Value Chain } \\
\text { Cost( }(04)\end{array}$ & $.191(.789)$ & 6.421 & 2.337 & & & \\
\hline & & other costs(05) & $.231(.749)$ & 9.657 & 1.81 & & & \\
\hline
\end{tabular}

Table 5 shows that, following the literature on structural equations (Fornell \& Larker, 1981; Samimi \& Mohammadi, 2011; Azar \& Gholamzadeh, 2016), for all constructs, AVE is higher than 0.5, So, convergent validity is in place. Cronbach's alpha coefficient and composite reliability were also higher than 0.7 for all variables. Therefore, the model has good reliability The VIF values for all the measures were within the range (.05), indicating that for the Formative construct, the linearity had 
not reached the critical level and there was no problem in estimating the PLS path model in the extended model.

\section{Hypotheses Testing and Results}

The most common measure used to evaluate a structural model is the coefficient of determination $\left(\mathrm{R}^{2}\right)$ ranging from 0 to 1 . The adjusted coefficient of determination also took into account the complexity of the model and sample size, both coefficients being close to 1 for all construct. As table 6 shows, the environmental construct with coefficient (0.997) posits the most impact, followed by the cost construct (0.996), technological construct (0.993) and organizational construct (0.981), respectively. Among the environmental constructs, the government support with a t-statistic of 17.928 and competition with t-statistic of 16.2 reveal a significant role in choosing the costing system and the type of strategy with a t-statistic of 11.276 and organizational culture with the t-statistic of 8.064 are in the following levels. In the cost constructs, the cost of maintaining a system with a t-statistic of 31.049 was crucial. In the technological constructs, the overhead volume with a t statistic of 17.139 had a significant influence on the choice of costing system and the complexity with a t statistic of 10.7 and then the variety of products manufactured with a t statistic of 6.062 were in the next category. Finally, there were organizational constructs in which the size of the organization with a t equivalent of 19.332 displayed the highest impact and the type of industry with a $t$ equivalent of 1.695 had the least impact on the adoption of the PFABC costing system. To test the research hypotheses, the coefficients of path (construct loadings) along with the t-statistic must also be calculated. If the calculated t-statistic is greater than 1.96, it indicates that the relationship between each question and the variable in question is significant. If, for a hypothesis, the value of $t$ be lower than the target value but the significance level calculated at the $95 \%$ confidence level be less than $5 \%$, that hypothesis is acceptable and statistically significant. For all the hypotheses, this value holds. In the first step for designing the structural model, the data collected by the questionnaire showed that the responses related to the other constructs were highly correlated and their external weights were not significant. As a result, these constructs were found not to be effective in implementing the PFABC costing system. Therefor the hypothesis was rejected. Table 6 shows the test results of the hypotheses. 
Table 6: Results of the Hypotheses

\begin{tabular}{|c|c|c|c|c|c|c|c|}
\hline Construct & $\mathbf{R}^{2}$ & $\begin{array}{l}\mathrm{R}^{2} \\
\text { adj }\end{array}$ & Hypotheses & t-statistic & $\begin{array}{l}\text { coefficients } \\
\text { of path }\end{array}$ & $\begin{array}{l}\text { Significance } \\
(P<05)\end{array}$ & $\begin{array}{l}\text { Hypothesis } \\
\text { test result }\end{array}$ \\
\hline \multirow{6}{*}{ Organizational } & \multirow{6}{*}{.981} & \multirow{6}{*}{.981} & $\begin{array}{l}\text { Senior } \\
\text { Manager } \\
\text { Support }\end{array}$ & 8.846 & .204 & o & Accepted \\
\hline & & & Staff Support & 6.123 & .253 & 0 & Accepted \\
\hline & & & Staff training & 5.15 & .195 & 0 & Accepited \\
\hline & & & $\begin{array}{l}\text { Type of } \\
\text { industry }\end{array}$ & 1.695 & .049 & o & Accepited \\
\hline & & & $\begin{array}{l}\text { Size of } \\
\text { organization }\end{array}$ & 19.332 & .612 & 0 & Accepted \\
\hline & & & $\begin{array}{l}\text { Willingness } \\
\text { to risk }\end{array}$ & 4.196 & .147 & o & Accepted \\
\hline \multirow{3}{*}{ Technological } & \multirow{3}{*}{.993} & \multirow{3}{*}{.993} & $\begin{array}{l}\text { Variety of } \\
\text { products }\end{array}$ & 6.062 & 299 & 0 & Accepted \\
\hline & & & $\begin{array}{l}\text { Complexity } \\
\text { of products }\end{array}$ & 10.7 & -443 & o & Accepited \\
\hline & & & $\begin{array}{l}\text { Overhead } \\
\text { volume }\end{array}$ & 17.139 & .565 & 0 & Accepted \\
\hline \multirow{4}{*}{ Invironmental } & \multirow{4}{*}{.997} & \multirow{4}{*}{.997} & $\begin{array}{l}\text { Type of } \\
\text { strategy }\end{array}$ & 11.276 & .252 & o & Accepited \\
\hline & & & Competition & 16.2 & -357 & 0 & Accepited \\
\hline & & & $\begin{array}{l}\text { Government } \\
\text { support }\end{array}$ & 17.928 & -487 & 0 & Accepited \\
\hline & & & $\begin{array}{l}\text { Role of } \\
\text { Culture }\end{array}$ & 8.064 & 244 & 0 & Accepited \\
\hline \multirow{2}{*}{ Cost } & \multirow{2}{*}{.996} & \multirow{2}{*}{.996} & $\begin{array}{l}\text { cost of } \\
\text { deployment }\end{array}$ & 6.822 & .309 & 0 & Accepted \\
\hline & & & $\begin{array}{l}\text { Maintenance } \\
\text { costs }\end{array}$ & 31.049 & .829 & o & Accepited \\
\hline
\end{tabular}

\section{Path Coefficients and $\mathrm{R}^{2}$ Value}

The structural model of the research was drawn based on the relationships between the reagents and the construct. Figure 4 discloses details of the relevant information. 


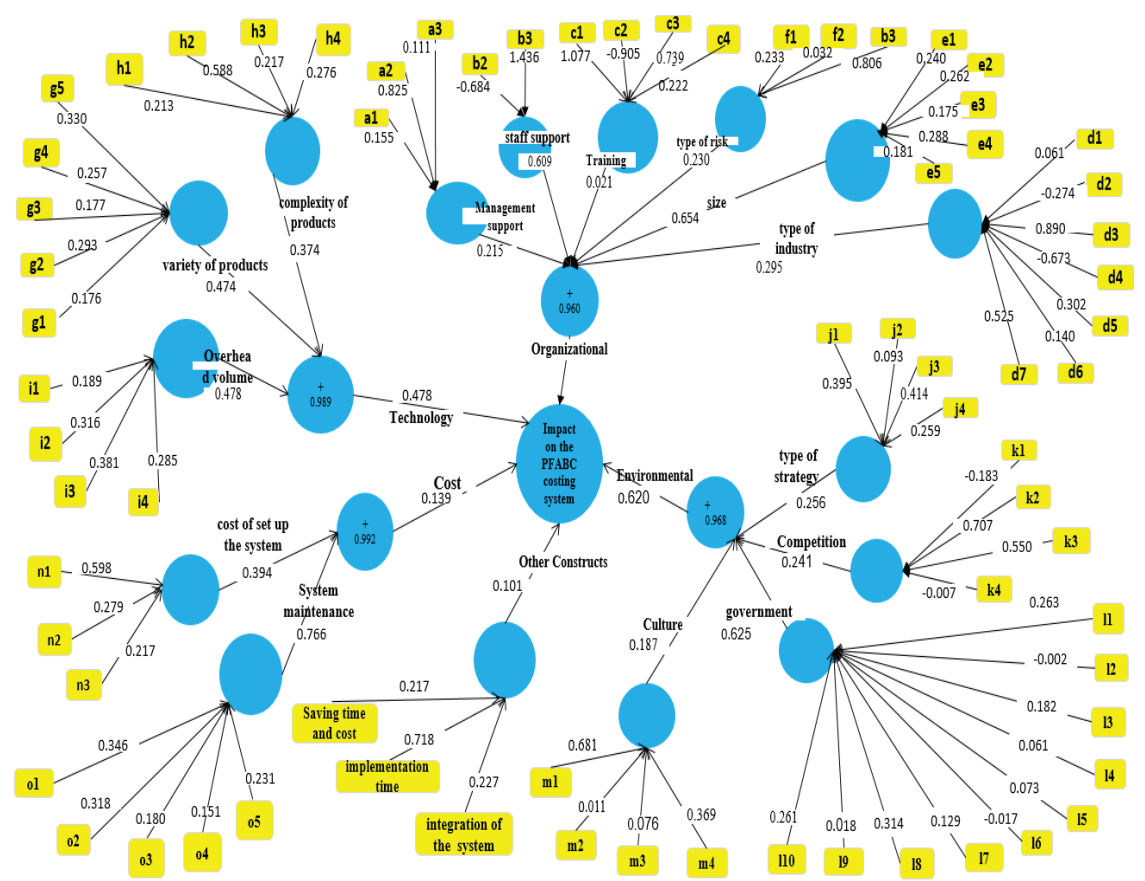

Figure 4: Path Coefficients and $\mathrm{R}^{2}$ Value

As the figure above shows, the PFABC costing system structure value is $(0.996)$ that confirms the suitability of the structural model. The path between organizational, technological, environmental, and cost construct also shows how much each of these constructs contribute to the adoption of the PFABC costing system. The hypothesis for the other constructs was rejected for the reasons which were mentioned. The strongest path belongs to the environmental construct (0.620) and the weakest path relates to other constructs (0.101). Among the environmental construct, the strongest criterion was the role of government (0.625) and the weakest criterion was the role of organizational culture (0.187). After the environmental construct, the organizational construct posited the strongest path (0.342). Organizational size (0.654) and employee training (0.021) were the most important and least important environmental criterions, respectively. The technology construct $(0.232)$ was ranked third important. The strongest criterion was the overhead volume $(0.478)$ and the weakest criterion was the complexity of the product type (0.374). Finally, the weakest path belonged to the cost construct (0.139). System maintenance costs $(0.766)$ 
was the most important criteria and system deployment costs $(0.394)$ the least important. In general, among all the surveyed constructs, system maintenance costs were recognized as the strongest and employee training as the weakest criterion.

\section{CONCLUSION AND DISCUSSION}

The major purpose of this study was to extract imputing constructs that should be selected for successful implementation of the PFABC, and to explore why there is a gap between theory and practice in this costing system. Our connotation was adoption and successful implementation of a new costing system (PFABC) depends on the attributes and constructing factors which are devised in its development stage. By selecting a mixed research methodology (Smith, 2019), developing a conceptual framework according to the content analysis, contingency, and innovation theories (Abrahamson, 1991; Rogers, 1995; Neuendorf, 2017; Zhang et al., 2017; Mazzarol \& Rebound, 2020), and adopting the survey method via SEM, the following conclusions are derived:

The results of this study, presented in Table 6 and Figure 4, confirms the foundations of the Contingent and Innovation Theories (Gosselin, 1997; Brown et al., 2004; Askarany \& Smith, 2008; Askarany et al., 2010; Elajili, 2015; Madwe, 2017). They unambiguously demonstrate that the design and successful implementation of a cost management system depends on identifying and combining various exogenous and endogenous constructs affecting the system. This is particularly true for an innovative technique like PFABC.

The results of hypotheses 1-4, shown in Table 6 and Figure 4, revealed that the most significant "constructs" affecting successful implementation of the PFABC system, as a whole, are: (1) environmental construct, (2) cost construct, (3) technological construct, and (4) organizational construct, respectively. However, there was no significant relationship between "other constructs" (the desire to save, system integration, time of system implementation) and implementation of the PFABC costing system (hypothesis 5). In addition, the first five "constructs of the constructs" that are effective in implementing the PFABC costing system are: (1) Maintenance 
cost (0.829), (2) Firm size (0.612), (3) Overhead volume (0.565), (4) Governmental support (0.487), and (5) Product complexity (0.443), which are related to the cost construct, organizational construct, and technological constructs, respectively. These findings provide an accurate list of imputing variables for practical application and implementation of the PFABC and other costing systems.

The results of testing the first hypotheses relating to the organizational construct, shown in Table 6 and Figure 4, indicate that organizational construct posits a significant influence on the implementation of the PFABC system. The strength of this construct in the path is also very high $\left(\mathrm{R}^{2}=0.981\right)$. The most influential variables of this construct affecting implementation of the PFABC based on the path coefficients are: (1) Size of the organization (0.612), (2) Staff support (0.253), (3) Top management support (0.204), (4) Staff training (0.195), (5) Willing to risk (0.147), and (6) Type of the industry (0.049), respectively. These results are interesting because they indicate that although top management support is important in adopting cost systems, this construct is not the most important variable, and is located as the third significant construct. This finding is also to some extent in contrast with the literature on the role of top management in the organization, and the importance of the type of the industry in cost management systems (Davila \& Foster, 2005), and confirms the literature which points out the importance of the size of the organization (Arora $\&$ Raju, 2017). It also emphasizes the role of staff supporting in the cost management process and supports the literature in this issue. In sum, the results of this hypothesis are consistent with the results of the studies of Brown et al. (2004), Zhang and Isa (2010), Askarany et al. (2012), Akinyomi (2013), Elagili (2015), Namazi and Nazemi (2015) and Madwe (2017).

The results of testing the second hypotheses relating to the technological construct, shown in Table 6 and Figure 4, indicate that this construct posits a significant impact on the implementation of the PFABC system. The strength of this construct in the model is also very high $\left(\mathrm{R}^{2}=\right.$ 0.993). The most significant variables of this construct are: (1) Overhead volume (0.565), (2) Complexity of products (0.443), and (3) Variety of products $(0.299)$, respectively. These findings are generally consistent with the ABC literature (Cooper \& Kaplan, 1998; Kaplan \& Anderson, 2007; Namazi, 2016a; 2016b). They confirm the assertion that the most important 
construct which has made traditional costing systems no longer meet the needs of the organization is the increase in overhead costs and how it should be allocated to products, and $\mathrm{ABC}$ implementation is particularly useful when the amount of overhead and complexity of the production of the product is high, and the variety of products exists in the organization. These findings are supported by the results of the studies of Krumwiede (1998), Brown et al. (2004), Abusalama (2008), Askarany and Smith (2008), Ahmadzadeh et al. (2011), Akinyomi (2013; 2014), Elagili (2015) and Madwe (2017), and it is in contrast with the results of Al-Omiri and Drury's (2007).

The results of testing the third hypothesis relating to the environmental construct, shown in Table 6 and Figure 4, revealed that this construct has a significant impact on the implementation of the PFABC system. The strength of this construct in the model is actually the highest $\left(\mathrm{R}^{2}=0.997\right)$ among different constructs. The most significant constructs of this construct are: (1) Government support (0.487), (2) Competition (0.357), (3) Type of strategy (0.252), and (4) Organizational culture (0.244), respectively. This finding provides empirical evidence concerning the importance of the role of government's support in developing cost systems, particularly when most of the business are controlled by the government. It also shows that competition is a key issue in the business world. Survival of organizations in this field depends on the absorption of new methods for each organization. External and intra-organizational culture are also constructs that posit a positive impact on the implementation of cost management system. Adoption of new and complex activity-based costing systems depends on people seeking to promote a culture of innovation in the organization. The results of this research is consistent with the studies of Brown et al. (2004), Al-Omiri and Drury (2007), Abusalama (2008), Askarany et al. (2010), Akinyomi (2013) and Elagili (2015).

The results of testing the fourth hypotheses relating to the cost of the system, shown in Table 6 and Figure 4, revealed that the cost construct has a significant impact on the implementation of the PFABC system. The strength of this construct in the model is also very high $\left(\mathrm{R}^{2}=0.996\right)$. The most significant constructs of this construct are: (1) maintenance costs of the system (0.829), and (2) the deployment costs (0.309), respectively. Maintenance costs are actually the most important construct affecting the 
implementation of the PFABC system among all constructs and constructs of the study. Deployment of any cost system in the organization is subject to the cost-benefit principle. After the installation of any system, the cost of maintenance and processing costs of the system provide a significant and positive role and can affect the survival or deterioration of the system. The results of this hypothesis are in line with the literature of ABC, particularly the studies of Cooper and Kaplan (1988), Shields (1995), Kaplan and Anderson (2007) and Namazi (2016a; 2016b).

The fifth hypothesis, relating to the effect of other constructs (saving time and cost, integration of PFABC system with other components, time of implementation of PFABC system) on the implementation of the PFABC, was rejected. One possible reason for rejecting this hypothesis is related to the high correlation of the constructs underlying this construct with other constructs, which was shown in Table 4. Another reason might be that since the implementation of the PFABC costing system is subject to 9 steps, respondents believe that this process is not only time consuming but also not cost saving for companies. On the other hand, it seems that due to the lack of knowledge and understanding of companies about the mechanism of this system, PFABC system integration with other sectors is not accepted by the respondents. The result of the above hypothesis is inconsistent with the results of Askarany and Smith (2003), Al-Omiri and Drury (2007), Akinyomi (2014) and Madwe (2017) studies.

The findings presented in Table 3, unambiguously demonstrate that there is a gap between theory and practice of cost systems. It showed that in 2018, most TSE companies (61.5\%) were still using traditional costing systems, $32.1 \%$ of them had adopted other cost systems, and the application of strategic cost systems of $\mathrm{ABC}$ and TDABC are only $6.1 \%$ and $0.4 \%$, respectively. The application of the PFABC has not been reported by TSE companies, although it has been reported by some other non- TSE organizations. The reasons for the gap between theory and practice can also be deduced from the information presented in Table 6 and Figure 4, and the lack of the necessary infrastructures, which are necessary for a successful implementation of these constructs. This finding is consistent with Cooper and Kaplan (1988), Askarany and Yazdifar (2007) and Jansen (2018). Another reason might be related to the unfamiliarity and reluctance of the managers and companies to adopt contemporary cost management 
techniques. Prior studies (Joshi, Bremser, Deshmukh, \& Kumar, 2011; Halbouni \& Nour, 2014) have reported that some managers, particularly in developing countries, insist on using traditional techniques and are reluctant to adopt contemporary systems.

We believe, by considering and adopting the constructs presented in this study, in future, the application of the PFABC system will increase and the gap between theory and practice will be diminished. As Section 3 (prior research) of this article revealed, applications of the PFABC in both manufacturing and service industries are now growing, and it is expected that the use of this system in Iran and abroad will increase in the future.

The importance of this study are: (1) it extended the theory of the ABC systems to PFABC systems and presented a conceptual model based on the contingency and innovation theories, (2) it identified the most significant constructs affecting the implementation of the PFABC systems empirically. Due to the comprehensiveness of this framework, it can be applied in various manufacturing as well as service industries in the world, and (3), it provided empirical evidence with respect to the gap between theory and practice in the sphere of cost management systems.

This study has practical implications. It empirically shows that although there has been some progress in the practical application of the PFABC, still there is a huge gap between its theory and practice. Furthermore, successful implementation of the PFABC costing system and attainment of the efficiency and effectiveness of the organization, requires considering a variety of hybrid combination of the organizational construct (particularly, size of the organization), technological constructs (particularly, overhead volume), environment constructs (particularly, governmental support) and cost constructs (particularly, implementation costs) in designing the system. Accountants, managers, and cost accounting systems' designers for instance would primarily benefit from the outcome of this study by studying, incorporating, and implementing the prescribed constructs and identified variables of each constructs of the system. This will lead to designing a finer cost accounting system with bigger potential thus helping various types of organizations in meeting their goals, purposes, and strategies. 
This study also extends the domain of the Expectancy Theory and Innovation Theory by providing another reason for adopting new costing systems and a successful implementation constructs of them. Specifically, we contend that adoption and successful implementation of a new costing system (PFABC) depends on the attributes and constructing factors (organizational, technological, environmental and cost) which are devised in its development stage. Since a systematic investigation of various attributes of this cost system has not yet been explored in the management accounting literature, this study provided an opportunity to investigate the casual relationships among innovation attributes for innovation adoption and successful implementation of it.

\section{SUGGESTIONS AND LIMITATIONS}

Although the focus of this research was on the PFABC system, most of these constructs are pervasive in that they can be extended to other contemporary costing systems and applied to variety of organizations. According to the constructs which were examined in Table 6, it is suggested that managers in different ranks, accountants, and other employees who are somehow involved in the application of organizational systems, including costing systems, broadly refer to the constructs presented in this study ( particularly cost of maintaining the system, size of the company, volume of the overhead, role of the government, and complexity of the products) and how they are applied to the organization and learn about the contingent constructs of their organizations.

Also, in each organization, a strategic management unit must be designated to investigate systemic innovations and assist the organization to survive in the field of competition, familiarity with government laws and regulations regarding new methods of costing systems and training required. Because some employees are often resistant to change, organizations and senior executives should think about motivating employees and adopting appropriate strategies such as motivational and financial incentives to align with organizational goals and make changes in the organization. Investigation of other organizational constructs, technological constructs, environmental constructs, and cost constructs affecting the implementation of costing systems is also recommended for future research. 
This study also has some limitations: difficulty in collecting questionnaire information, lack of the existence of a standard questionnaire regarding the designated constructs, and lack of familiarity of a majority of respondents with modern costing systems are some of the limitations. Despite these limitations, an extensive attempt was made to maintain the validity and reliability of the study as much as possible.

\section{ACKNOWLEDGEMENT}

We sincerely would like to express our thanks and appreciation to the anonymous reviewers for their constructive comments which greatly enhanced the quality of this article.

\section{REFERENCES}

Abrahamson, E. (1991). Managerial fads and fashions: The diffusion and rejection of innovations. Academy of Management Review, 16(3), 586-612.

Abusalama, F.A. (2008). Barriers to adopting activity-based costing systems $(A B C)$ : An empirical investigation using cluster analysis (Doctoral dissertation, Dublin Institute of Technology).

Ahmadzadeh, T., Etemadi, H., \& Pifeh, A. (2011). Exploration of constructs influencing on choice the activity-based costing system in Iranian organizations. International Journal of Business Administration, 2(1), $61-71$.

Akinyomi, O. J. (2013). Assessment of constructs influencing costing system implementation in Nigeria. International Journal of Information, Business and Management, 5(1), 139-149.

Akinyomi, O. J. (2014). Effects of product diversity on activity-based costing system implementation in Nigeria. International Journal of Marketing and Technology, 4(2), 45-54. 
Ali, A. M. M. (2019). The role of performance focused activity based costing (PFABC) in productivity improving and performance evaluating, Case study in the general company for tire industry in Najaf-Iraq. International Journal of Multidisciplinary Research and Publications, $2(6), 35-41$.

Al-Omiri, M., \& Drury, C. (2007). A survey of constructs influencing the choice of product costing systems in UK organizations. Management Accounting Research, 18(4), 399-424.

Arora, A. K., \& Raju, M. S. S. (2017). The effect of firm's size on the adoption and implementation of activity based costing. Splint International Journal of Professional, 4(7), 36-40.

Askarany, D., \& Smith, M. (2003). The relationship between technological innovation, activity based costing and business size (Doctoral dissertation, Informing Science Institute).

Askarany, D., \& Smith, M. (2008). Diffusion of innovation and business's size: A longitudinal study of PACIA. Managerial Auditing Journal, 3(9), 900-916.

Askarany, D., \& Yazdifar, H. (2007). Why ABC is not widely implemented? International Journal of Business, 7(1), 93-98.

Askarany, D., Brierley, J. A., \& Yazdifar, H. (2012). The effect of innovation characteristics on activity-based costing adoption. International Journal of Managerial and Financial Accounting, 4(3), 291-313.

Askarany, D., Smith, M., \& Yazdifar, H. (2007). Technological innovations, activity based costing and satisfaction. Journal of Accounting-Business \& Management, 14, 53-63.

Askarany, D., Yazdifar, H., \& Askary, S. (2010). Supply chain management, activity-based costing and organisational factors. International Journal of Production Economics, 127(2), 238-248.

Azar, A., \& Gholamzadeh, R. (2016). Partial least squares structural equation modelling. Tehran: Negahedanesh. 
Birkinshaw, J. M., \& Mol, M. J. (2006). How management innovation happens. MIT Sloan Management Review, 47(4), 81-88.

Brown, D. A., Booth, P., \& Giacobbe, F. (2004). Technological and organizational influences on the adoption of activity-based costing in Australia. Accounting \& Finance, 44(3), 329-356.

Carroll, N., \& Lord, J. C. (2016). The growing importance of cost accounting for hospitals. Journal of Health Care Finance, 43(2), 171-185.

Cooper, R., \& Kaplan, R. S. (1988). Measure costs right: Make the right decisions. Harvard Business Review, 66(5), 96-103.

Davila, A., \& Foster, G. (2005). Management accounting systems adoption: Evidence and performance implications from early-stage / start-up companies. Accounting Review, 80(4), 1039-1068.

Dianatideilami, Z., Alambeigi, A., \& Khatibi, H. (2016). Investigation of the impact of environmental uncertainty on the effectiveness of management practices tools. Journal of Management Auditing and Accounting Knowledge, 5(17), 87-98.

Elagili, G. (2015). Adoption constructs for the implementation of activity based costing systems: A case study of the Libyan cement industry (Doctoral dissertation, University of Salford).

Fornell, C., \& Larcker, D. F. (1981). Evaluating structural equation models with unobservable variables and measurement error. Journal of Marketing Research, 18(1), 39-50.

Ghadimpour, J., \& Shahvalizade, A. (2014). From the Traditional Activity Based Costing System to the Performance-Focused Activity-Based Costing (PFABC). In 1th National Conference in Economic Management and Iranian Islamic Culture, University of Isfahan.

Gosselin, M. (1997). The effect of strategy and organizational structure on the adoption and implementation of activity-based costing. Accounting, Organizations and Society, 22(2), 105-122. 
Halbouni, S. S., \& Nour, M. A. (2014). An empirical study of the drivers of management accounting innovation: A UAE perspective. International Journal of Managerial and Financial Accounting, 6(1), 60-86.

Harder, M. (2011). Internal antecedents of management innovation [Doctoral dissertation, Department of Strategic Management and Globalization (SMG), Copenhagen Business School].

Hassoun, L. N. (2019). The role of performance focused activity based costing (PFABC) in the institutional excellence/Field study on Babylon Bank. Tikrit Journal of Administrative and Economic Sciences, 4(44), 28-49.

Jansen, E. P. (2018). Bridging the gap between theory and practice in management accounting. Accounting, Auditing \& Accountability Journal, 31(5), 1486-1509.

Johnson, H. T., \& Kaplan, R. S. (1987). Relevance lost: The rise and fall of management accounting. Boston, Mass: Harvard Business School Press.

Joshi, P. L., Bremser, W. G., Deshmukh, A., \& Kumar, R. (2011). Diffusion of management accounting practices in Gulf Cooperation Council Countries. Accounting Perspectives, 10(1), 23-53.

Kaplan, R. S., \& Anderson, S. R. (2007). Time-driven activity-based costing: A simpler and more powerful path to higher profits. Boston: Harvard Business School Press.

Kowsari, F. (2013). Changing in costing models from traditional to performance focused activity based costing (PFABC). European Online Journal of Natural and Social Sciences, 2(3), 2497-2508.

Krumwiede, K. R. (1998). The implementation stages of activity-based costing and the impact of contextual and organizational factors. Journal of Management Accounting Research, 10, 239-277.

Madwe, M. C. (2017). Adoption of activity-based costing at technical and vocational education and training in KwaZulu-Natal (Doctoral dissertation, Durban University of Technology, South Africa). 
Mazzarol, T., \& Reboud, S. (2020). Entrepreneurship and innovation: Theory, practice and context. Singapore: Springer.

Moghri, E., Kordlouie, H. R., \& Varmazyar, M. (2019). Performance focus on activity based costing model, evaluation at Sina Bank. Journal of Interdisciplinary Research, 8(2), 110-120.

Nagirikandalage, P., \& Binsardi, B. (2017). Inquiry into the cultural impact on cost accounting systems (CAS) in Sri Lanka. Managerial Auditing Journal, 32(4/5), 463-499.

Namazi, M. (1998-1999). A review of the activity based costing system in management accounting and its behavioural considerations. Journal of Accounting and Auditing Review, 7(26-27), 71-106.

Namazi, M. (2009). Performance-focused ABC: A third generation of activity-based costing system. Cost Management, 23(5), 34-46.

Namazi, M. (2016a). Time-driven activity-based costing: Theory, applications and limitations. Iranian Journal of Management Studies, 9(3), 457-468.

Namazi, M. (2016b). Emergence of the time-driven activity-based costing. International Review of Management and Business Research, 5(3), 1008-1020.

Namazi, M., \& Moghimi, F. (2018). Effects of innovations and moderating role of corporate social responsibility on the financial performance of the firms listed on the Tehran Stock Exchange in different industries. Journal of Accounting and Auditing Review, 25(2), 289-310.

Namazi, M., \& Nazemi, A. (2015). The usefulness of cost information and determination of major constructs affecting implementation of the activity based costing (The case of Bank Keshavarzi Iran). Journal of Empirical Research in Accounting, 4(15), 105-127.

Namazi, M., \& Shamsaldini, K. (2016). Investigation of the impact of learning on the performance-focused activity-based costing (PFABC). Journal of Management Accounting, 9(29), 73-87. 
Neuendorf, K. A. (2017). The content analysis guidebook ( $2^{\text {nd }}$ ed.). Thousand Oaks, CA: Sage.

Ostadi, B., Daloie, R. M., \& Sepehri, M. M. (2019). A combined modelling of fuzzy logic and Time-Driven Activity-based Costing (TDABC) for hospital services costing under uncertainty. Journal of Biomedical Informatics, 89, 11-28.

Petera, P., \& Šoljaková, L. (2020). Use of strategic management accounting techniques by companies in the Czech Republic. Economic Research, $33(1), 46-67$.

Reyhanoghlu, M. (2004). Activity-based costing system advantages and disadvantages. Retrieved from https://papers.ssrn.com/sol3/ papers. cfm?abstract_id $=644561$

Rickards, R. C., \& Ritsert, R. (2018). Organisational influences on management accounting toolkits in Chinese enterprises: an exploratory study. International Journal of Managerial and Financial Accounting, 10(1), 16-31.

Rogers, E. M. (1995). Diffusion of innovation ( $4^{\text {th }}$ ed.). New York: Free Press.

Samimi, A., \& Mohammadi, R. (2011). Measuring customer satisfaction index (CSI) in Iranian tile industry using PLS path modelling technique. Middle-East Journal of Scientific Research, 8(1), 141-149.

Sarokolaei, M. A., Bahreini, M., \& Bezenjani, F. P. (2013). Fuzzy performance focused activity based costing (PFABC). Procedia-Social and Behavioral Sciences, 75, 346-352.

Sarokolaei, M. A., Saviz, M., Moradloo, M. F., \& Dahaj, N. S. (2013). Time driven activity based costing by using fuzzy logics. Procedia-Social and Behavioral Sciences, 75, 338-345.

Shields, M. D. (1995). An empirical analysis of firms' implementation experiences with activity-based costing. Journal of Management Accounting Research, 7(1), 148-165. 
Smith, M. (2019). Research methods in accounting ( $5^{\text {th }}$ ed.). London, UK: Sage Publications.

Toompuu, K., \& Põlajeva, T. (2014). Theoretical framework and an overview of the cost drivers that are applied in universities for allocating indirect costs. Procedia-Social and Behavioral Sciences, 110, 1014-1022.

Toosi, H., \& Chamikarpour, A. (2019). Designing a cost control system to increase competitiveness in construction projects based on the integration of PFABC and TC. Journal of Management Accounting Research, 12(40), 47-61.

Zhang, Y. F., \& Isa, C. R. (2010). Behavioral and organizational variables affecting the success of $\mathrm{ABC}$ success in China. African Journal of Business Management, 4(11), 2302-2308.

Zhang, Y. F., Namazi, M., \& Isa, C. R. (2017). Investigating the empirical effect of ABC stages on the performance of companies. Iranian Journal of Management Studies, 10(1), 175-205. 